FACTA UNIVERSITATIS

Series: Economics and Organization Vol. 18, No 3, 2021, pp. 229 - 242

https://doi.org/10.22190/FUEO210501016O

Original Scientific Paper

\title{
HOW DID COVID-19 PANDEMIC AFFECT THE TOURISM INDEX IN BORSA ISTANBUL?
}

\author{
UDC 338.48:[616.98:578.834(560)
}

\section{Ercan Özen ${ }^{1}$, Letife Özdemir ${ }^{2}$}

${ }^{1}$ University of Uşak, Faculty of Applied Sciences, Uşak, Turkey

${ }^{2}$ University of Afyon Kocatepe, Afyonkarahisar, Turkey

$\begin{array}{lll}\text { ORCID iD: } & \text { Ercan Özen } & \text { (1) htps://orcid.org/0000-0002-7774-5153 } \\ & \text { Letife Özdemir } & \text { (i) https://orcid.org/0000-0002-8636-2277 }\end{array}$

\begin{abstract}
This study aims to determine how and to what extent the Covid-19 pandemic impacted the Turkish tourism sector index in Borsa İstanbul. Daily data for the period from March $27^{\text {th }} 2020$ to December $31^{\text {st }} 2020$ were used to find the relationship between the dependent variable (BIST tourism stock index) and the independent variables (Covid-19 cases and deaths in Turkey). The cointegration relationship between the Covid-19 pandemic and the BIST tourism index was investigated with the ARDL bound test. In addition, the effect of the Covid-19 pandemic on the BIST tourism index was tested with the Cointegrating Regression Models. As a result of the ARDL bound test, it was determined that there is a long-term cointegration relationship between the Covid-19 pandemic and the BIST tourism index. In addition, it has been determined that the impact of the short-term shocks caused by Covid-19 on the BIST tourism index will disappear in the long term and will balance again in about a week. According to the Cointegrating Regression Models (FMOLS, DOLS and $C C R$ ) results, it is seen that the deaths from Covid-19 significantly affect the tourism index. According to the models, a 1\% increase in the number of deaths causes the BIST tourism index to decrease by $0.08 \%, 0.06 \%$ and $0.08 \%$, respectively. The coefficient of the number of Covid-19 cases is not significant, showing that the number of cases does not have a sufficient effect on the tourism index. The findings of the paper have some implications for stock investors, policy makers, academicians and the company owners in the tourism index of Borsa Istanbul.
\end{abstract}

Key words: Covid-19 Pandemic, BIST Tourism Index, ARDL Bound Test,

Cointegrating Regression Models

JEL Classification: G10, D53, Z33

Received May 01, 2021 / Accepted August 16, 2021

Corresponding author: Ercan Özen

University of Uşak, Faculty of Applied Sciences, Ankara Izmir Highway 8. Km. 1 Eylül Campus 64200 Uşak,

Turkey | E-mail: mailto:ercan.ozen@usak.edu.tr

(๑) 2021 by University of Niš, Serbia | Creative Commons Licence: CC BY-NC-ND 


\section{INTRODUCTION}

With the outbreak of Covid-19, which was declared as an epidemic by the World Health Organization (WHO) on March $11^{\text {th }}, 2020$, Turkey, along with the whole world, entered a serious crisis environment. As of January $15^{\text {th }}, 2021$, there are more than 94 million confirmed COVID-19 cases and over 2 million deaths in 221 countries. As of this date, it is seen that the five countries most affected by COVID-19 are the USA, India, Brazil, Russia and UK, respectively. Turkey, among countries affected by the pandemic Covid-19 is located as $9^{\text {th }}$. . On January $15^{\text {th }} 2021$, a total of $2,373,115$ people were infected and 23,664 people died (www.worldometers.info).

As seen in Figure 1, the first wave was experienced in Turkey in April 2020, with the number of infected reaching 10,000 per day. The daily number of cases, which remained low from June to November, reached its second peak in December 2020 (35,000 per day). The number of cases, which decreased again, exceeded 63,000 daily at the end of April 2021, and the third wave was seen. With the intense restrictions applied in the same period and the start of vaccination, the number of daily cases decreased to 5,000 at the end of June 2021 (Figure 1).

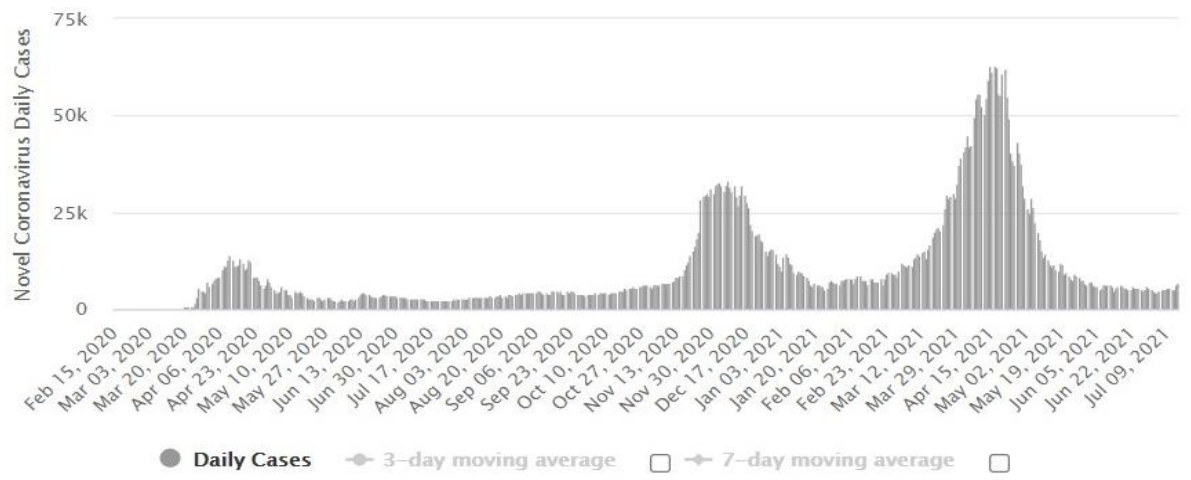

Fig. 1 Daily Covid-19 Cases in Turkey Source: Derived from www.worldometers.info, 2021.

The continuation of the pandemic has also negatively affected the Turkish tourism sector. As of 2019, Turkey was among the top 5 countries in the world with 51 million annual visitors and 34 million USD tourism income. Tourism revenues are of vital importance in terms of Turkey's balance of payments. However, as can be seen in Table 1, 2020 has had profound effects on the Turkish tourism sector. According to Table 1, the number of tourists and tourism income decreased to zero in April-May and June immediately after the Pandemic declaration. After this dramatic situation, annual tourism income remained at the level of 12 million USD (65\% decrease) and the number of tourists remained at the level of 15.8 million (69\% decrease).

Although decreases are seen in the tourism index due to the number of cases and deaths caused by Covid-19, upward movements have emerged in the index again with the expectations that vaccine development and vaccination activities will start in the world.

In 2020, there were 8 tourism companies (Avtur, Ayces, Maalt, Mart1, Metur, Tektu, Ulas and Utopia) in the tourism index of Borsa Istanbul ${ }^{2}$. These companies are largely hotels that

\footnotetext{
${ }^{2}$ https://www.kap.org.tr/tr/Endeksler, Accessed on 31.12.2020
} 
provide for customers from abroad. Therefore, these companies were significantly negatively affected by the pandemic.

Table 1 Tourism income and number of visitors by months in Turkey, 2019-2020

\begin{tabular}{|c|c|c|c|c|c|c|}
\hline \multirow[b]{2}{*}{ Months } & \multicolumn{3}{|c|}{2019} & \multicolumn{3}{|c|}{$2020^{(1)}$} \\
\hline & $\begin{array}{l}\text { Tourism } \\
\text { income } \\
(000 \$)\end{array}$ & $\begin{array}{c}\text { Number of } \\
\text { visitors }\end{array}$ & $\begin{array}{c}\text { Average } \\
\text { expenditure } \\
\text { per capita }(\$)\end{array}$ & $\begin{array}{l}\text { Tourism } \\
\text { income } \\
(000 \$)\end{array}$ & $\begin{array}{c}\text { Number of } \\
\text { visitors }\end{array}$ & $\begin{array}{c}\text { Average } \\
\text { expenditure } \\
\text { per capita }(\$)\end{array}$ \\
\hline Total & $34,520,332$ & $51,860,042$ & 666 & $12,059,320$ & $15,826,266$ & 762 \\
\hline January & $1,585,517$ & $2,226,288$ & 712 & $1,834,008$ & $2,529,423$ & 725 \\
\hline February & $1,359,194$ & $1,944,957$ & 699 & $1,479,447$ & $2,051,923$ & 721 \\
\hline March & $1,684,968$ & $2,473,147$ & 681 & 787,750 & $1,058,068$ & 745 \\
\hline April & $1,996,446$ & $3,266,256$ & 611 & - & - & - \\
\hline May & $2,639,675$ & $4,219,837$ & 626 & - & - & - \\
\hline June & $3,337,843$ & $5,276,253$ & 633 & - & - & - \\
\hline July & $4,384,887$ & $6,703,045$ & 654 & 561,409 & 777,043 & 722 \\
\hline August & $5,244,124$ & $8,167,150$ & 642 & $1,622,303$ & $2,192,917$ & 740 \\
\hline September & $4,402,111$ & $6,741,769$ & 653 & $1,860,644$ & $2,634,195$ & 706 \\
\hline October & $4,101,484$ & $5,437,494$ & 754 & $2,054,889$ & $2,355,124$ & 873 \\
\hline November & $2,138,195$ & $3,005,517$ & 711 & $1,051,951$ & $1,262,757$ & 833 \\
\hline December & $1,645,890$ & $2,398,329$ & 686 & 806,918 & 964,816 & 836 \\
\hline
\end{tabular}

Note: Figures in table may not add up to totals due to rounding.

(1) Annual data for 2020 include the data for 1st, 3rd and 4th quarters.

'- Data related to the 2 nd quarter of 2020 was not published because survey could not be conducted at border gates due to coronavirus (COVID-19) pandemic.

Calculations are made by extracting the departures of Syrians from the Gaziantep Kargamış, Hatay

Cilvegözü and Yayladağı, Kilis Öncüpınar and Şanlıurfa-Akçakale border gates from the border figures of General Directorate of Security.

Source: Turkish Statistical Institute, TurkStat Departing Visitors Survey, 2021.

Globally, the Covid-19 pandemic causes many businesses to close, production to stop, consumption to decline, and unemployment to rise. The economic effects of the epidemic are being felt decidedly between countries and sectors, which negatively affects financial markets. The Covid-19 pandemic did not affect sectors at the same level. While some sectors are turning this into an opportunity, companies in some sectors are at risk of bankruptcy. Companies in areas such as pharmaceuticals, food, cleaning, chemicals and telecommunication are among those positively affected by the pandemic.

While human mobility was a major factor in the spread of the Covid-19 epidemic, tourism was one of the sectors most affected due to measures taken to restrict this mobility. Covid-19 pandemic causes significant damage to the tourism sector, therefore its effects on the tourism index need to be investigated. Because, in terms of trading volume and market value, Borsa İstanbul is among the top 30 stock exchanges in the world and the top 3 stock exchanges in terms of trading turnover rate. The high speed of trading turnover indicates that Borsa Istanbul is one of the most liquid stock markets in the world. On the other hand, there are thousands of active and potential investors who have invested in the stocks of tourism companies traded on this exchange. In order for investors to decide to invest in companies included in the tourism index, it is also necessary to analyze the relationship between the number of cases and deaths related to the pandemic and the tourism index.

The purpose of this study is to investigate the impact of the Covid-19 pandemic on the tourism industry. For this purpose, in order to see the impact of the Covid-19 pandemic, the 
daily total number of cases and deaths and the BIST tourism sector stock index representing the tourism sector were included in the analysis. In the study, it was tried to determine whether there is a long-term relationship between Covid-19 and the tourism index by ARDL bound test using daily data for the period of 27.03.2020 - 31.12.2020. In addition, the impact of the Covid-19 pandemic on the tourism index was investigated using the Cointegrating Regression Models (FMOLS, DOLS and CCR).

In this study, the current literature investigating the impact of the Covid-19 pandemic on markets is included in section two. The research methodology is presented in the section three and the data in the section four. The study is completed with the fifth section, where the results of empirical analysis are evaluated.

\section{LITERATURE REVIEW}

The Covid-19 pandemic has had profound effects on the world economy and financial markets. Numerous academic studies published since the first cases and deaths have sought to guide policymakers by analyzing the effects of the pandemic on the economy and financial markets. Zeren and Hizarcı (2020) found that all stock market indices involved in their study with deaths caused by Covid-19 move together in the long term. However, while there is a long-term relationship between the total number of Covid-19 cases and the SSE, KOSPI and IBEX35 markets, there is no long-term relationship between the FTSE, MIB, CAC40 and DAX30 markets. Liu et al. (2020) determined that the indices declined rapidly after the Covid-19 outbreak. In their study, Zhang, et al (2020) determined that a high correlation emerged between stock returns and the Covid19 pandemic after the outbreak of the pandemic.

Al-Awadhi et al. (2020) found that stock returns were significantly negatively correlated with daily increases in both cases and deaths. Similarly, Şenol and Zeren (2020) found that there is a long-term relationship between the stock markets and Covid-19 data. Yan (2020) and Liew (2020) revealed in their study that the COVID-19 outbreak caused stock prices to fall sharply.

Saka Ilgın \& Sarı (2020) determined a causal relationship from the number of cases and deaths to stock markets in the USA, India, Brasil, Colombia and Turkey. On the other hand, the studies of Alber (2020) and Ashraf (2020) show that the sensitivity of the indices to the number of cases is stronger than the number of deaths.

Lin \& Falk (2021) investigated the changes in the return and volatility of travel and entertainment indices of 3 Nordic countries due to Covid-19 during the period of June 2018 to June 2020. The authors determined that there was a regime change during the study period. According to the results of the study, while Pandemic increased the performance of gambling businesses, it had a negative impact on international transportation, the hotel and restaurant businesses. Lee et al (2020) stated that during the first wave of the pandemic, the KLCI index and all sub-indices were adversely affected, except for the Real Estate sector index in Malaysia.

There are also studies in the literature examining the impact of the Covid-19 pandemic on Turkish financial markets (Kandil Göker et al., 2020; Öztürk et al., 2020; Tayar et al., 2020; K1lıç, 2020; Özdemir, 2020; Korkut et al., 2020). Kandil Goker et al. (2020) found that the highest decreases in the Covid-19 period were in the Sports, Tourism and Transport indices. Ozturk et al. (2020), in his study, especially metal products, machinery, sports, tourism, transportation, banking and insurance sectors were determined to be among the most affected sectors, while food, beverage, wholesale and retail trade were determined as less affected 
sectors. In the study of Kilıç (2020) it was determined that the textile and tourism sectors were exposed to the highest negative impact, while it was concluded that the trade sector provided positive returns during the epidemic process. Tayar et al. (2020), in their study, determined that the Covid-19 epidemic had significant and negative effects on the Electricity, Transportation, Financial, Industrial, Technology Sectors, while significant effects were not reached in the Food-Beverage, Trade, Textile, Tourism and Services sectors.

Korkut et al. (2020) determined that both the daily number of Covid-19 cases and the number of daily deaths from Covid-19 have a cointegrated structure with the BIST Tourism index. It has been understood that the pandemic data has a negative relationship with the BIST tourism index in the short term, and a positive relationship in the long term. Ege \& Metin (2021), on the other hand, investigated the impact of the first Covid-19 news in Turkey. According to the study, on food and tourism indexes, the first news of Covid-19 had a positive effect on the food index and a negative effect on the tourism index.

\section{Methodology}

In order to examine the impact of the Covid-19 pandemic on the tourism index, it was first tested whether there was a long-term relationship between the variables. Later, the Cointegrating regression models were established to see the impact levels of the Covid19 pandemic on the tourism index.

\subsection{Auto Regressive Distributed Lag (ARDL) Bound Test}

Cointegration implies that variables move together in the long run. Engle and Granger (1987), Johansen (1988) and Johansen \& Juselius (1990) cointegration tests, which are called classical cointegration tests, test the long-term relationship between stable variables of the same order. On the other hand, in the ARDL bound test approach developed by Peseran et al. (2001), it is possible to test the cointegration relationship between variables regardless of the constraint of the variables being stationary to the same degree. Since the variables used in the study are stationary at different levels, the ARDL bound test was used as a cointegration test.

In order to determine whether there is cointegration between variables with the ARDL bound test, it is necessary to establish an unrestricted error correction model first. Equation 1 based on the Error Correction Model used in this study is as follows (Polat and Gemici, 2017):

$$
\begin{aligned}
& \Delta \text { lnTourism }=\beta_{0}+\sum_{1=1}^{M} \beta_{1 i} \Delta \text { lnTourism }_{t-i}+\sum_{1=1}^{M} \beta_{2 i}{\text { sln } \text { Case }_{t-i}} \\
& \begin{array}{l}
+\sum_{i=1}^{M} \beta_{3 i} \Delta \text { lnDeath }_{t-i}+\beta_{4} \text { lnTourism }_{t-1}+\beta_{5}{\text { ln } \text { Case }_{t-1}} \\
+\beta_{6} \text { lnDeath }_{t-1}+\mu_{t}
\end{array}
\end{aligned}
$$

This equation shows that is the first difference and $\mathrm{m}$ is the appropriate number of lags. Here, whether there is cointegration between variables is determined by the $\mathrm{F}$ test. The calculated F statistic is compared with the critical values in Peseran et al.'s (2001) studies. If the F statistic is greater than the lower and upper critical values, it is decided that there is cointegration, if it is between two critical values, the situation is uncertain, if it is below the critical values, it is decided that there is no cointegration. After the cointegration relationship is found, the long-term relationship between the variables is predicted with the conditional ARDL model shown in equation 2. 


$$
\begin{aligned}
\Delta \text { lnTourism }= & \beta_{0}+\sum_{\mathrm{i}=1}^{M} \beta_{1 i} \text { InTourism }_{t-i}+\sum_{\mathrm{i}=1}^{M} \beta_{2 i} \text { InCase }_{t-i} \\
& +\sum_{\mathrm{i}=1}^{M} \beta_{3 i} \Delta \text { lnDeat }_{t-i}+\mu_{t}
\end{aligned}
$$

The variables in the above equation have already been defined in the section above. This step involves finding the most suitable ARDL (p, q) model with the help of Akaike information criterion (AIC). In the last stage, short term parameters are obtained by estimating the error correction model associated with long term parameters. This relationship is given as follows in Equation (3):

$$
\begin{aligned}
\Delta \text { lnTourism }= & \beta_{0}+\sum_{\mathrm{i}=1}^{M} \beta_{1 i} \Delta \text { lnTourism }_{t-i}+\sum_{\mathrm{i}=1}^{M} \beta_{2 i} \Delta \text { lnCase }_{t-i} \\
& +\sum_{\mathrm{i}=1}^{M} \beta_{3 i} \Delta \text { lnDeat }_{t-i}+\theta \text { ECM }_{t-1}+\mu_{t}
\end{aligned}
$$

The $\theta$ in the above equation is speed of adjustment and ECM represents the error correction term, which is calculated from the estimated equilibrium relationship established in equation (1). The speed of adjustment constitutes the speed at wich disturbance created by short run shock reaches back to long run equilibrium.

\subsection{Cointegrating Regression Models}

When the variables are cointegrated, a relationship occurs between explanatory variables and error terms, and this situation creates an endogeneity problem. In this case, the variables lose their asymptotic properties. Three methods, Full Modified Ordinary Least Square (FMOLS), Dynamic Ordinary Least Square (DOLS) and Canonical Cointegration Regression (CCR) have been proposed to overcome these problems. All of these methods make various transformations about variables in order to eliminate the endogeneity problem (Berke, 2012).

In the FMOLS estimator, asymptotic bias and externality assumption is used to compensate for the inability of the OLS estimator to calculate optimal values of the cointegrated equations (Chen \& Huang, 2013). FMOLS estimator assumes the existence of a single cointegrated vector (Phillips and Hansen, 1990). The FMOLS estimator uses a quasi-parametric correction method to avoid prediction problems caused by the long-term correlation between the cointegrated equation and stochastic shocks. Consequently, the estimator is fully efficient and asymptotically neutral, allowing standard Wald tests using the asymptotic $\chi 2$ distribution.

The canonical least squares method (CCR) expressed by Park (1992) is similar to the FMOLS estimation. The CCR method uses the stationary transformations of the data to eliminate the long-term correlation between shocks in the cointegration equation and stochastic variables in determining the least squares estimation.

Dynamic Least Squares Method (DOLS) was developed by Stock and Watson (1993). The DOLS method is a method that can eliminate the deviations in static regression (especially caused by endogeneity problems) by including dynamic elements in the model. In addition, the method determines the long-term coefficients between variables by adding the preliminary and lagged values of the difference of independent variables to the model. 


\section{DATA}

The purpose of the study is to determine how and to what extent the Covid-19 pandemic impacted the tourism sector. For this purpose, the number of cases caught in the Covid-19 pandemic and the number of people who died from the pandemic in Turkey with the BIST Tourism sector stock index are included as variables. In the study, it was analyzed using daily data for the period 27.03.2020 - 31.12.2020. The reason for the data period to start from 27.03.2020 is that the Covid-19 virus was first seen in Turkey in March. The data of the Covid-19 pandemic was taken from the Turkish Republic Ministry of Health Covid-19 information platform and stock index data was taken from the investing.com database. The relationship between the Covid-19 pandemic and the tourism stock index was analyzed using the Eviews package program by taking the logarithm of the daily data of the variables. Graphical representation of the variables used in the study is given in figure 2.
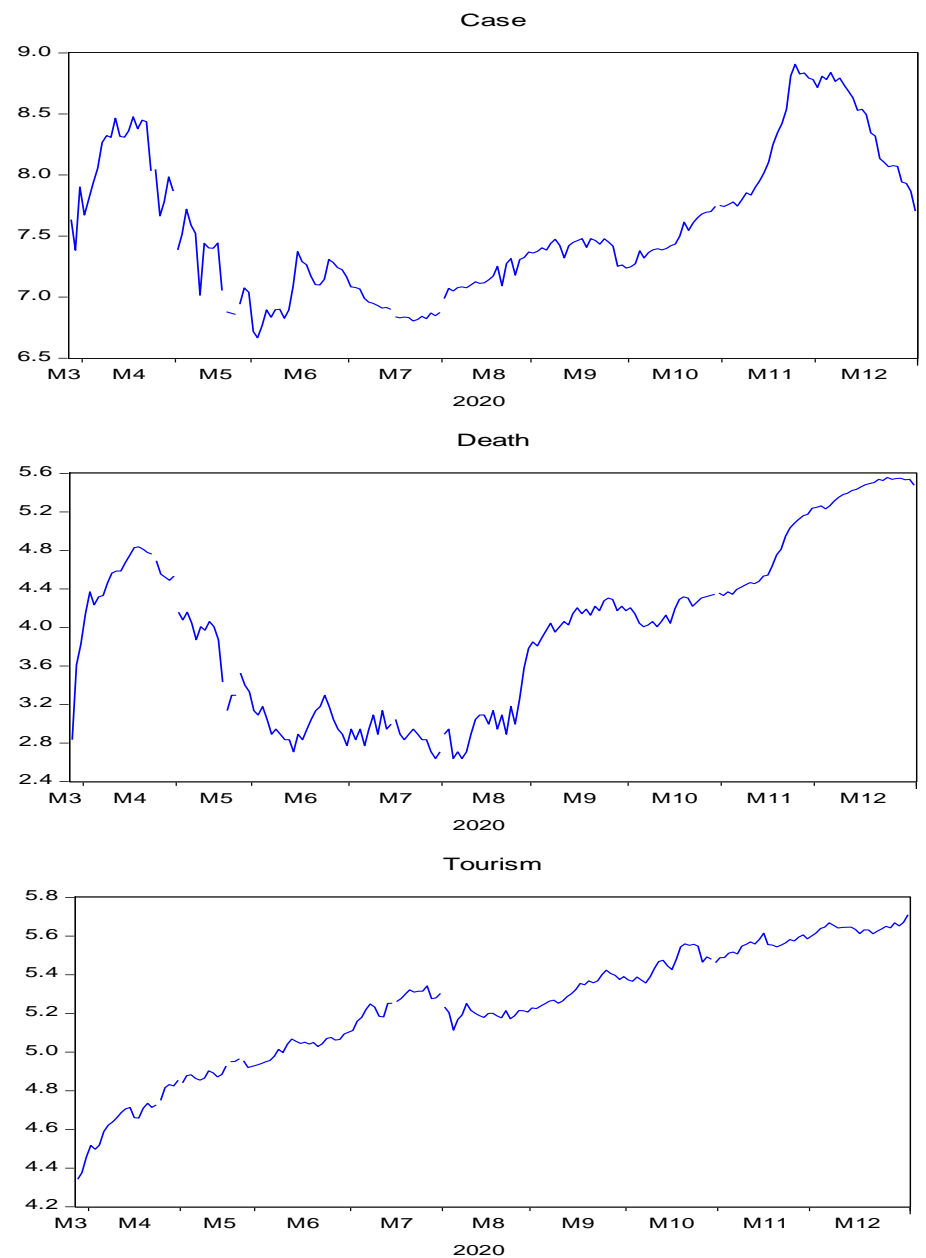

Fig. 2 Graphics of Covid-19 Incident and Death Numbers and Tourism Index Series Source: Prepared by the author 
The statistical characteristics of the Covid-19 case and death and BIST Tourism index series are shown in Table 2. It is seen that the number of Covid-19 deaths has a high standard deviation according to the number of cases. This situation indicates that the number of deaths exhibit high volatility. The fact that the calculated Jarque-Bera values of the series are statistically significant indicates that the series are not normally distributed.

Table 2 Descriptive Statistics

\begin{tabular}{lccc}
\hline & Tourism & Case & Death \\
\hline Mean & 5.224974 & 7.574138 & 3.971848 \\
Median & 5.251278 & 7.421178 & 4.060443 \\
Maximum & 5.710195 & 8.906664 & 5.556828 \\
Minimum & 4.342506 & 6.666957 & 2.639057 \\
Std. Dev. & 0.316691 & 0.581665 & 0.869617 \\
Skewness & -0.549196 & 0.659028 & 0.146325 \\
Kurtosis & 2.594380 & 2.447038 & 1.923885 \\
Jarque-Bera & 10.91080 & 16.25920 & 9.897532 \\
J-B Probability & 0.004273 & 0.000295 & 0.007092 \\
Observations & 191 & 191 & 191 \\
\hline \multicolumn{4}{c}{ Source: Compiled by the authors }
\end{tabular}

\section{ANALYSIS AND FINDINGS}

Before looking at the relationship between the Covid-19 case and death numbers and industry stock indices, it was examined whether the series were stationary or not. For stationarity analysis, ADF (Extended Dickey-Fuller) unit root test developed by Dickey and Fuller (1979) and PP (Phillips-Perron) unit root test developed by Phillips Perron (1990) were used. The unit root test results for the regression models in which the series have constant terms, constant terms and trend terms are presented in Table 3.

Table 3 ADF and PP Unit Root Test Results

\begin{tabular}{|c|c|c|c|c|c|c|}
\hline \multirow{2}{*}{ Variables } & & \multicolumn{2}{|c|}{$\begin{array}{l}\text { Augmented Dickey-Fuller } \\
\text { (ADF) Test }\end{array}$} & \multicolumn{2}{|c|}{$\begin{array}{l}\text { Philips-Perron } \\
\text { (PP) Test }\end{array}$} & \multirow[t]{2}{*}{$\begin{array}{c}\text { Stationary } \\
\text { Level }\end{array}$} \\
\hline & & Intercept & $\begin{array}{c}\text { Trend and } \\
\text { Intercept }\end{array}$ & Intercept & $\begin{array}{l}\text { Trend and } \\
\text { Intercept }\end{array}$ & \\
\hline Tourism & Level & $-3.0204^{* *}$ & $-4.4889^{* * * *}$ & $-3.1046^{* *}$ & $-4.4791^{* * * *}$ & $\mathrm{I}(0)$ \\
\hline \multirow[t]{2}{*}{ Case } & Level & -1.4357 & -1.6630 & -1.3753 & -1.6028 & \\
\hline & Difference & $-15.1533^{* * *}$ & $-15.1066^{* * * *}$ & $-15.1127^{* * * *}$ & $-15.067^{* * *}$ & $\mathrm{I}(1)$ \\
\hline \multirow[t]{2}{*}{ Death } & Level & -0.6815 & -1.0382 & -0.9458 & -1.3054 & \\
\hline & Difference & $-14.2892^{* * * *}$ & $-14.3409^{* * * *}$ & $-14.2580^{* * * *}$ & $-14.431^{* * *}$ & $\mathrm{I}(1)$ \\
\hline
\end{tabular}

Source: Compiled by the authors

When Table 3 was examined, according to the unit root test results, it was revealed that the Tourism index series did not have a unit root in both the ADF test and the PP test. Thus, the null hypothesis that there is a unit root in the series is rejected and it is concluded that the level value of the series is stationary I(0). It has been revealed that the 
Covid-19 case and death series have a unit root. Thus, it is concluded that the null hypothesis that there is unit root in the series is accepted and that the series are not stationary in the level values. When the first difference of the series is taken, the null hypothesis that it has unit root is rejected at the $1 \%$ significance level. Thus, the series has become stationary $\mathrm{I}(1)$ in the first difference.

\subsection{ARDL Method}

In the ARDL method, first of all, it should be tested whether there is a long-term relationship between variables. To perform the ARDL test, an appropriate lag number is selected according to the Akaike information criterion (AIC). The most suitable lag number was chosen by taking the maximum lag 4 . It has been determined that it is the most suitable ARDL $(1,0,3)$ model according to the AIC information criterion. The most appropriate ARDL $(1,0,3)$ bound test model and F statistics created to measure whether there is a cointegration relationship between Covid-19 case and death numbers and tourism index are given in Table 4.

Table 4 Results of ARDL Bound Test

\begin{tabular}{ccccc}
\hline Model & F-statistic & Significance & $\mathrm{I}(0)$ Bond & $\mathrm{I}(1)$ Bond \\
\hline & & $\% 10$ & 4.307 & 5.223 \\
ARDL $(1,0,3)$ & $7.099779^{* *}$ & $\% 5$ & 5.067 & 6.103 \\
& & $\% 1$ & 6.73 & 8.053 \\
\hline
\end{tabular}

*** indicate statistical significance at the 5 percent levels. Source: Compiled by the authors

Since the calculated $\mathrm{F}$ statistic is greater than the critical values at the 5\% importance level, it is understood that the Covid-19 case and death numbers and the tourism index are long-term co-integrated in the relevant period. After confirming that there is a longterm relationship between variables, it is possible to examine the long and short-term effects. Long and short term coefficient estimates calculated for ARDL $(1,0,3)$ model are presented in Table 5.

The term shown by ECM (Error Correction Model) in the table is the error correction term. The error correction coefficient of the model (-0.139) is negative and statistically significant at $1 \%$ significance level. This shows that the error correction model of the model works and the model is meaningful. This situation shows that in the case of a shock occurring in the short term, $14 \%$ of this shock will disappear in each period in the long term and it may return to balance in about seven periods (about a week).

In order for the results obtained from the model to be reliable, it must provide some assumptions. Diagnostic tests performed to test these assumptions are given in Table 6 . Here; Breusch - Godfrey is used to test the autocorrelation problem, ARCH value is used to test the variance problem and the Ramsey Reset test is used to test the error of setting up the model. Since the probability values of all tests are not significant at the significance levels, it is understood that the model does not contain autocorrelation and changing variance and does not contain modeling errors. In other words, since the model provides the necessary assumptions, it can be stated that the results obtained are reliable. 
Table 5 Results of ARDL Long-Term and Short-Term

\begin{tabular}{|c|c|c|c|c|}
\hline \multicolumn{5}{|c|}{ Long Run Coefficients } \\
\hline Variable & Coefficient & Std. Error & t- statistic & Prob. \\
\hline lncase & -0.016166 & 0.048660 & -0.332229 & 0.7401 \\
\hline lndeath & -0.021977 & 0.035653 & -0.616407 & 0.5384 \\
\hline $\mathrm{c}$ & $4.974469^{* * * *}$ & 0.261871 & 18.995859 & 0.0000 \\
\hline @ trend & $0.005388^{* * *}$ & 0.000318 & 16.917399 & 0.0000 \\
\hline \multicolumn{5}{|c|}{ Error Correction Form } \\
\hline Variable & Coefficient & Std. Error & $\mathrm{t}$ - statistic & Prob. \\
\hline $\mathrm{D}($ lncase $)$ & -0.002255 & 0.006770 & -0.333037 & 0.7395 \\
\hline $\mathrm{D}$ (lndeath) & -0.018114 & 0.017679 & -1.024576 & 0.3069 \\
\hline $\mathrm{D}($ lncase $(-1))$ & -0.009536 & 0.022540 & -0.423047 & 0.6728 \\
\hline $\mathrm{D}(\operatorname{lnc} \operatorname{case}(-2))$ & -0.019192 & 0.015399 & -1.246353 & 0.2143 \\
\hline D(@trend) & $0.000751^{* * *}$ & 0.000197 & 3.806344 & 0.0002 \\
\hline ECM & $-0.139470^{* * *}$ & 0.032360 & -4.309980 & 0.0000 \\
\hline
\end{tabular}

*** indicate statistical significance at the 1 percent levels. Source: Prepared by the authors

Table 6 Results of Diagnostic Test

\begin{tabular}{lc}
\hline Test & Statistic (Prob.) \\
\hline ARCH LM & $0.045287(0.8317)$ \\
Breusch-Godfrey & $0.791976(0.4545)$ \\
Ramsey Reset & $0.328268(0.5674)$ \\
\hline
\end{tabular}

Source: Prepared by the authors

Finally, CUSUM and CUSUMQ graphs developed by Brown et al. (1975) were used to determine whether there was a structural break in the predicted model. These graphs investigate whether there is any structural break in variables using the squares of recycled residuals. CUSUM and CUSUMQ graphics are shown in Figure 3
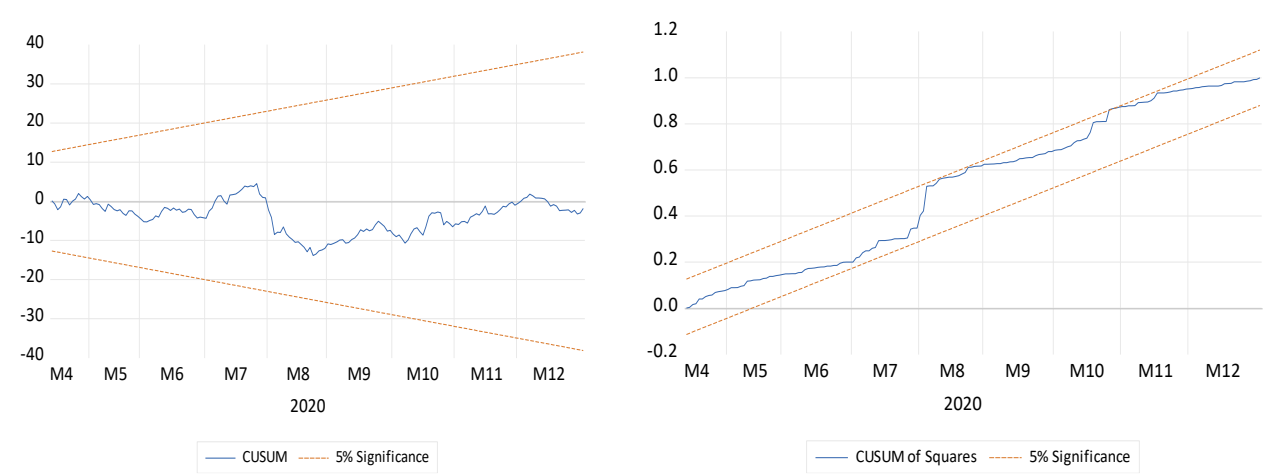

Fig. 3 Graphics of CUSUM and CUSUMQ

If the CUSUM and CUSUMQ graphs do not exceed the critical limits at the 5\% significance level, it is decided that the estimated long-term coefficients are consistent. When Figure 3 is examined, it is seen that CUSUM and CUSUMQ graphs are within 
critical limits. Therefore, it is possible to say that the long-term coefficients between variables are consistent.

\subsection{Cointegrating Regression Models}

At the last stage of the study, the FMOLS, DOLS and CCR regression models were used to estimate the coefficients of the tourism index with the Covid-19 case and death numbers, with a long-term relationship between them. The model equation established for this purpose is as follows.

$$
\text { lnTourism }=\beta_{0}+\beta_{1} \ln \text { Case }+\beta_{2} \ln \text { Death }+\varepsilon
$$

In the equation, $\varepsilon$ denotes the error term of the model. As a result of the FMOLS, DOLS and CCR regression models, it was tried to determine whether the Covid-19 cases and death numbers had any effect on the Tourism Index and the effect size. As a result of the analysis, the results of the test statistics regarding the coefficients of the independent variables in the model and the significance of the coefficients are given in Table 7.

Table 7 Results of FMOLS, DOLS and CCR Regression Models

\begin{tabular}{|c|c|c|c|c|c|c|}
\hline \multirow[b]{2}{*}{ Variables } & \multicolumn{2}{|c|}{ FMOLS } & \multicolumn{2}{|c|}{ DOLS } & \multicolumn{2}{|c|}{ CCR } \\
\hline & Coefficient & t- statistic & Coefficient & t- statistic & Coefficient & t- statistic \\
\hline lnCase & 0.027815 & 0.619611 & 0.003624 & 0.106916 & 0.032623 & 0.700095 \\
\hline lnDeath & -0.078747 & $-2.416905^{* *}$ & -0.063987 & $-2.603810^{* * * *}$ & -0.082190 & $-2.443067^{* *}$ \\
\hline $\mathrm{C}$ & 4.756811 & $19.82259^{* * * *}$ & 4.889903 & $27.47325^{* * *}$ & 4.732980 & $19.09300^{* * * *}$ \\
\hline$@$ Trend & 0.006055 & $22.61963^{* * * *}$ & 0.005985 & $33.00882^{* * * *}$ & 0.006064 & $22.75532^{* * * *}$ \\
\hline & \multicolumn{2}{|c|}{$\begin{array}{c}\mathrm{R}^{2}=0.955952 \\
\text { Adj. } \mathrm{R}^{2}=0.955241\end{array}$} & \multicolumn{2}{|c|}{$\begin{array}{c}\mathrm{R}^{2}=0.966328 \\
\text { Adj. } \mathrm{R}^{2}=0.964626\end{array}$} & \multicolumn{2}{|c|}{$\begin{array}{c}\mathrm{R}^{2}=0.955596 \\
\text { Adj. } \mathrm{R}^{2}=0.954879\end{array}$} \\
\hline
\end{tabular}

When the results of the FMOLS regression model were examined, it was determined that the deaths of Covid-19 affect the tourism index at a 5\% significance level. A $1 \%$ increase in the number of deaths causes the tourism index to decrease by $0.08 \%$. The fact that the coefficient of the number of Covid-19 cases was not found to be significant shows that this variable did not have a sufficient effect on the tourism index in the relevant period.

As a result of the DOLS regression model, the effect of Covid-19 deaths on the tourism index was found to be significant at $1 \%$ significance level, while the effect of the number of cases on the tourism index was not statistically significant. According to the DOLS regression model, a $1 \%$ increase in the number of deaths in Covid-19 causes the tourism index to decrease by $0.06 \%$.

As a result of the CCR regression model, it was seen that the effect of Covid-19 death numbers on the tourism index was statistically significant, and the effect of the number of cases on the tourism index was not statistically significant. According to the CCR regression model, a $1 \%$ increase in the number of deaths in Covid-19 causes the tourism index to decrease by $0.08 \%$. Results obtained as a result of FMOLS, DOLS and CCR regression models support each other. The high $\mathrm{R}^{2}$ values $(0.955,0.966$ and 0.955$)$ of the established Cointegrating Regression Models indicate that the variables explain the highly dependent variable. 


\section{CONCLUSION}

Financial markets are quickly affected by social and economic factors. The Covid-19 epidemic spread rapidly all over the world and created a crisis environment. When the COVID-19 outbreak was declared by the World Health Organization as a global pandemic, significant declines occurred in financial markets around the world. Even if the crisis in a country affects financial markets negatively, sectors can be affected by this situation in different ways. Therefore, how the Covid-19 pandemic affects the Tourism industry of Turkey is the subject of the study. The BIST tourism stock index to represent the tourism sector and the number of people caught in the epidemic and the number of people who died to represent the Covid-19 pandemic were taken as variables. The Covid-19 virus was first seen in March in Turkey. Therefore, in the study, daily data for the period 27.03.2020 - 31.12.2020 were used in the analysis.

In order to examine the relationship between the Covid-19 case and death numbers and the BIST tourism index, it is necessary to test whether the series are stationary or not. As a result of the ADF and PP unit root tests, it was determined that the BIST tourism index was stable at level, and the Covid-19 case and death numbers were stable at the first difference. ARDL method was used to determine the existence of long-term cointegration relationship between variables that are differently stationary. It has been determined that it is the most suitable ARDL $(1,0,3)$ model according to the AIC information criterion. As a result of the ARDL $(1,0,3)$ model, it was determined that there was a long-term equilibrium relationship between variables during the analysis period. This result supports the cointegration test results of the study conducted by Zeren and Hizarc1 (2020), Şenol and Zeren (2020) and Korkut et al. (2020). The error correction coefficient of the model (-0.139) is negative and statistically significant at $1 \%$ significance level. This situation shows that in the case of a shock occurring in the short term, $14 \%$ of this shock will disappear in each period in the long term and it may return to balance in about seven periods (about a week).

Since there is cointegration between variables, the Cointegrating Regression Models (FMOLS, DOLS and CCR) have been applied to see the effect of Covid-19 case and death numbers on the BIST tourism index. The results of FMOLS DOLS and CCR regression models support each other. According to the results of the cointegrating regression models, the effect of the number of Covid-19 cases on the tourism index was not significant, while the effect of the number of Covid-19 deaths on the tourism index was determined to be significant and negative. According to the findings, a $1 \%$ increase in the number of deaths causes the tourism index to decrease by $0.08 \%$ according to the FMOLS model, $0.006 \%$ according to the DOLS model and $0.08 \%$ according to the CCR model. The conclusion that the Covid-19 pandemic has a negative impact on the tourism sector is supported by the studies of Kandil Göker et al. (2020), Kılıç (2020) and Korkut et al. (2020). However, we can say that the findings of this study do not comply with findings of Alber (2020) and Ashraf (2020), because they determine the case effect is more powerful than death numbers effect.

This paper gives us the information on the effect of changes on Covid-19 pandemics cases and deaths numbers on the tourism index of Borsa İstanbul. So this is the originality of the present paper.

Within the framework of these results, investors can accurately evaluate their investments by analyzing the reactions of sectors in BIST to the Covid-19 pandemic. In other words, there is also the possibility that investors can turn the Covid-19 pandemic into an opportunity. In future studies, the returns of the stocks of companies included in the BIST tourism index can be estimated by examining the level of exposure to the Covid-19 pandemic. 
Acknowledgement: The paper is expanded and renewed version of the conference paper presented in International Scientific Conference "Tourism and the Global Crises", held in Veliko Tarnovo Bulgaria in 21 April 2021.

\section{REFERENCES}

Al-Awadhi, A. M., Al-Saifi, K., Al-Awadhi, A., \& Alhamadi, S. (2020). Death and Contagious Infectious Diseases: Impact of the COVID-19 Virus on Stock Market Returns. Journal of Behavioral and Experimental Finance, 27, 1-5. https://doi.org/10.1016/j.jbef.2020.100326

Alber, N. (2020). The Effect of Coronavirus Spread on Stock Markets. The Case of the Worst 6 Countries. http://ssrn.com/abstract $=3578080$

Ashraf B. N. (2020). Stock Markets' Reaction to COVID-19: Cases or fatalities?. Research in International Business and Finance, 54, 1-7. https://doi.org/10.1016/j.ribaf.2020.101249

Berke B. (2012). Exchange Rate and IMKB100 Index Relationship: A New Test (in Turkish), Maliye Dergisi, 163 , pp. 243-257.

Brown, R. L., Durbin, J., \& Evans, J. M. (1975). Techniques for Testing the Constancy of Regression Relationships over Time. Royal Statistical Society, 37(2), 149-192.

Chen, J. H., \& Huang, Y. F. (2013). The Study of the Relationship between Carbon Dioxide (CO2) Emission and Economic Growth. Journal of International and Global Economic Studies, 6(2), 45-61.

Dickey, D. A., \& Fuller, W. A. (1979). Distribution of the Estimators for Autoregressive Time Series with a Unit Root. Journal of the American Statistical Association, 74, 427-431. https://doi.org/10.2307/2286348

Ege, İ, \& Metin, S. (2021). Türkiye'de İlk Covid-19 Vakası Haberinin Pay Piyasasına Etkisi: Bist Gıda ve Turizm Endeksleri Üzerine Bir Uygulama [The Effect of The News of The First Covid-19 Case in Turkey on The Stock Market: An Application on BIST Food and Tourism Indices]. İktisadi ve İdari Yaklaşımlar Dergisi (Journal of Economic and Administrative Approaches), 3(1), 44-58.

Engle, R. F., \& Granger, C. W. (1987). Co-integration and Error Correction: Representation, Estimation and Testing. Econometrica, 55(2), 251-276. https://doi.org/10.2307/1913236

Johansen, S. (1988). Statistical Analysis of Cointegration Vectors. Journal of Economics Dynamic and Control, 12(2-3), 231-254. https://doi.org/10.1016/0165-1889(88)90041-3

Johansen, S., \& Juselius, K. (1990). Maximum Likelihood Estimation And Inference On Co-integration: With Application to The Demand For Money. Oxford Bulletin of Economics and Statistics, 52, 169-210. https://doi.org/10.1111/j.1468-0084.1990.mp52002003.x

Kandil Göker, E., Eren, B. S., \& Karaca, S. S. (2020). The Impact of the COVID-19 (Coronavirus) on The Borsa Istanbul Sector Index Returns: An Event Study. Gaziantep University Journal of Social Sciences 2020 Special Issue, 14-41. https://doi.org/10.21547/jss.731980

Kilıç, Y. (2020). The Effect of COVID-19 (Coronavirus) in Borsa Istanbul. Journal of Emerging Economies and Policy, 5(1), 66-77. Retrieved from https://dergipark.org.tr/tr/pub/joeep/issue/53777/734904

Korkut, Y., Eker, M., Zeren, F., \& Altunış1k, R. (2020). The Impact Of Covid-19 Pandemic On Tourism: A Study on Borsa İstanbul Tourism Indices. Gaziantep University Journal of Social Sciences Special Issue, 71-86. https://doi.org/10.21547/jss.774557

Lee, K. Y. M., Jais, M., \& Chan, C. W. (2020). Impact of covid-19: evidence from Malaysian stock market. International Journal of Business and Society, 21(2), 607-628. https://doi.org/10.33736/ijbs.3274.2020

Liew, V. K. S. (2020). The effect of novel coronavirus pandemic on tourism share prices. Journal of Tourism Futures, (ahead-of-print). https://doi.org/10.1108/JTF-03-2020-0045

Lin, X., \& Falk, M. T. (2021). Nordic stock market performance of the travel and leisure industry during the first wave of Covid-19 pandemic. Tourism Economics, 1(18), https://doi.org/10.1177/1354816621990937

Liu, H., Manzoor, A., Wang, C., Zhang, L., \& Manzoor, Z. (2020). The COVID-19 Outbreak and Affected Countries Stock Markets Response. International Journal of Environmental Research and Public Health, 17(8). http://dx.doi.org/10.3390/ijerph17082800

Özdemir, L. (2020). Asymmetric Effects Of Covid-19 Pandemic on BIST Sector Indices. Research of Financial Economic and Social Studies (RFES), 5(3), 546-556. http://dx.doi.org/10.29106/fesa.797658

Öztürk, Ö., Şişman, M. Y., Uslu, H., \& Çitak, F. (2020). Effect of COVID-19 Outbreak on Turkish Stock Market: A Sectoral-Level Analysis. Hitit University Journal of Social Sciences Institute, 13(1), 56-68. https://doi.org/10.17218/hititsosbil.728146

Park, J. (1992). Canonical Cointegrating Regressions. Econometrica, 60, 119-143. https://doi.org/10.2307/2951679

Perron, P. (1990). Testing for a unit root in a time series with a changing mean. Journal of Business and Economic Statistics, 8, 153-162. https://doi.org/10.2307/1391823 
Pesaran, M. H., Shin, Y., \& Smith, R. J. (2001). Bounds Testing Approaches to the Analysis of Level Relationships. Journal of Applied Econometrics, 16(3), 289-326. https://doi.org/10.1002/jae.616

Phillips, P., \& Hansen, B. (1990). Statistical Inference in Instrumental Variables Regression with I(1) Processes. Review of Economic Studies, 57, 99-125. https://doi.org/10.2307/2297545

Polat, M., \& Gemici, E. (2017). Analysis of the Relationship between BIST and BRICS Stocks in Terms of Portfolio Diversification: Cointegration Analysis with ARDL Boundary Test. Journal of Economics, Finance and Accounting (JEFA), 4(4), 393-404. http://doi.org/10.17261/Pressacademia.2017.749

Saka Ilgın, S., \& Sarı, S. S. (2020). COVID-19 Pandemisinin Hisse Senedi Piyasalarına Etkisi: Vaka ve Ölümlerin Yoğun Olduğu Ülkeler ile Türkiye İncelemesi [The Impact of COVID-19 Pandemic on Stock Markets: Investigation of Countries with Intensive Case and Deaths and Turkey]. Karadeniz Sosyal Bilimler Dergisi, 12(23), 434-453. https://doi.org/10.38155/ksbd.812580

Stock, J., \& Watson, M. (1993). A Simple Estimator of Cointegrating Vectors in Higher Order Integrated Systems. Econometrica, 61(4), 783-820. https://doi.org/10.2307/2951763

Şenol, Z. \& Zeren, F. (2020). Coronavirus (Covid-19) and Stock Markets: The Effects of the Pandemic on the Global Economy. Avrasya Sosyal ve Ekonomi Araştırmaları Dergisi, 7(4), 1-16.

Tayar, T., Gümüştekin, E., Dayan, K., \& Mandi, E. (2020). The Effects of Covid-19 Crisis on Industries in Turkey: The Study of Borsa Istanbul Industrial Indices. Van YYU The Journal of Social Sciences Institute, Outbreak Diseases Special Issue, 293-320.

Turkish Statistical Institute, TurkStat Departing Visitors Survey, 2021.

Worldmeter, (2020). Covid-19 Coronavirus Pandemic. https://www.worldometers.info/coronavirus/\#countries, Accessed: 1 February 2021

Yan, C. (2020). COVID-19 Outbreak and Stock Prices: Evidence from China. http://ssrn.com/abstract=3574374

Zeren, F., \& Hizarc1, A. (2020). The Impact of Covid-19 Coronavirus on Stock Markets: Evidence From Selected Countries. Muhasebe ve Finans Incelemeleri Dergisi, 3(1), 78-84. https://doi.org/10.32951/mufider.706159

Zhang, D., Hu, M., \& Ji, Q. (2020). Financial Markets under the Global Pandemic of COVID-19. Finance Research Letters, 36, 101528. https://doi.org/10.1016/j.frl.2020.101528

Republic of Turkey Ministry of Health (2020). COVID-19 Information Page https://covid19.saglik.gov.tr/ , Accessed: 1 February 2021

https://www.investing.com/, Accessed: 1 February 2021

https://www.kap.org.tr/tr/Endeksler, Accessed on 31.12.2020

https://www.worldometers.info/coronavirus/country/turkey/\#graph-cases-daily, Accessed on 07.07.2021

\section{KAKO JE PANDEMIJA KOVID-19 UTICALA NA INDEKS TURIZMA NA ISTAMBULSKOJ BERZI?}

Ovaj rad ima za cilj da utvrdi kako i u kojoj meri je pandemija Kovid 19 uticala na turski sektor turizma na istambulskoj berzi (BIST). Dnevni podaci za period od 27. marta 2020 do 31. decembra 2020 su korišćeni da bi se odredio odnos između zavisne varijabile (BIST berzanski indeks turizma) $i$ nezavisne varijabile (broj slučajeva $i$ umrlih od Kovid 19 u Turskoj). Kointegracijski odnos između pandemije Kovid 19 i BIST indeksa turizma istražen je korišćenjem ARDL bound testa. Osim toga, efekti pandemije Kovid 19 na BIST berzanski indeks turizma testirani su uz pomoć kointegracijskog modela regresije. Kao rezultat ARDL testa, utvrđeno je da postoji dugoročna kointegracijska veza između pandemije Kovid 19 i BIST indeksa turizma. Osim toga, utvrđeno je da će uticaj kratkoročnih šokova koje je Kovid 19 izazvao na BIST indeks turizma nestati na duge staze $i$ ponovo se izbalansirati za oko nedelju dana. Prema rezultatima kointegracijskoh modela regresije (FMOLS, DOLS $i$ CCR), vidi se da smrtnost od Kovid 19 značajno utiče na sektor turizma. Prema modelima, 1\% povećanje u broju smrtnih slučajeva izaziva pad BIST indeksa turizma za 0.08\%, 0.06\% odnosno 0.08\%. Koeficijent broja Kovid 19 slučajeva nije značajan, što pokazuje da broj slučajeva nema značajnog efekta na indeks turizma. Rezultati ovog rada imaju neke implikacije za investiture na berzi, kreatore politika, akademike $i$ vlasnike kompanija iz indeksa turizma na istambulskoj berzi.

Ključne reči: Pandemija Kovid 19, BIST indeks turizma, ARDL Bound Test, kointegracijski regresioni modeli 